\title{
ANALYSING HIGHER ORDER THINKING SKILLS ON THE COMPULSORY ENGLISH TEXTBOOK FOR TENTH GRADERS OF INDONESIAN SENIOR HIGH SCHOOLS
}

\author{
Andi Sukmawijaya'; Wisma Yunita²; Dedi Sofyan ${ }^{3}$ \\ Universitas Bengkulu1,2,3 \\ Corresponding email: andi.sukmawi@gmail.com
}

\begin{abstract}
This study aimed to ascertain proportion of Higher Order Thinking Skills (HOTS) based on the revised edition of Bloom's Taxonomy in the language skills and language knowledge of tasks in the textbook of "Bahasa Inggris of class ten employed in senior, vocational and Islamic senior high schools published by the Ministry of Education of the republic of Indonesia and its relevancy to the 2013 curriculum. By employing a content analysis research design, this study employed content cards as the instrument for analysing the textbook, in which two techniques were used to administer the data, namely content analysis and documentation. The data were analysed qualitatively using Brookhart including compiling, disassembling, reassembling, interpreting and concluding. Results turned out that the proportion of HOTS in language skills is integrated well. In addition, the content of higher-order thinking skills in tasks of the compulsory English textbook of "Bahasa Inggris of class ten employed in senior, vocational and Islamic senior high schools" is relevant to the 2013 curriculum. It has fulfilled the standard suggested by the Decrees of the Ministry of Education. It is recommended that the teachers need to train students extensively on the implementation of the HOTS to achieve the goals targeted in the 2013 curriculum well.
\end{abstract}

Keywords: Compulsory English Textbook, Higher Order Thinking Skills (HOTS)

\section{INTRODUCTION}

The textbook has a significant role in the teaching learning process. It can decide what a teacher must instruct and what a student has to learn. Based on the 2013 curriculum, standardized process as listed in the Decree of the Ministry of Education Number 22 of 2016 consists of planning, implementation and, assessment. Learning planning includes preparation of 
learning implementation plan, learning resource, relevancy, learning assessment tool and learning scenario. The learning implementation includes pre, while and post-teaching that is adapted to the learning principles of the 2013 curriculum.

At that point, the textbook serves the students accomplishment in certain subjects such as the English textbook provides specific methods such as proper instructional materials (Whitehurst et al., 2014), collaborative learning and a process of engagement, exploration, explanation, elaboration and, evaluation (Mutrofin et al., 2017). Tomlinson (2009) point out that everything that is used to help teaching language for learners is classified as material in language learning. Furthermore, Rahmawati (2013) reveals in her research that a textbook contains ready-made materials and becomes the easiest and the cheapest way to help teachers run the learning process. There are some characteristics of textbooks, such as: it has needs, interest and abilities of the students, suit the teacher, and meet the need of official public teaching syllabus or examination.

More importantly, textbooks are should be used by the schools relevant with the implementation of the 2013 curriculum. English textbooks designed for students of SVHSs should be oriented to develop the students' thinking skills. This is supported by the empirical evidence which strongly claims that it is important to promote higher order thinking skills in the process of English language teaching and learning (Brookhart, 2010).

In the level of secondary schools, SVHs (Senior and Vocational High Schools), Higher order thinking skills (HOTS) is crucial parts in teaching and learning. Thinking skills are fundamental in educational process. A student thought can affect the ability of learning, speed and effectiveness of learning (Kiong et al., 2012). Therefore, thinking skills is associated with learning process in Indonesian Senior High Schools. The Students who are trained to think demonstrate a positive impact on the development of their education to university.

Hence, the implementation of learning Higher Order Thinking Skills (HOTS) in senior high schools based on Bloom's taxonomy is additionally related to other criteria such as multiple intelligences, critical thinking, problem solving skills and more recently language integration skills. The characteristic of the textbook should be designed from lower to higher-order thinking skills. This process begins with the knowledge to the comprehension level that recently coming to the highest level known as evaluation. The arrangement of questions ought to be made according to their level of difficulty. Most critically, great exam questions are planned to test and measure students' multiple skills and levels of understanding (Hiu et al, 2006). 
The results of study appeared that there was a positive correlation between higher order thinking skills and learning achievement. Tomlinson et al (2009) responds that high order thinking skill is thinking at higher level than simply remembering fact or retelling something heard to other. HOTS in senior high schools also has gotten to be a major objective of education and is one of the beat five variables that can make strides student's achievement.

Despite many studies that have detailed on the utilize of HOTS in instructing and learning, not much have been done on the four skills in English. Most of the previous studies stated above are related to the textbook evaluation which are tend to know the quality of the English textbook by evaluating the content of the textbook with a theory proposed by an expert. The difference between this research and those studies mentioned is this study tries to analyze the HOTS of an English textbook especially of four skills (reading, listening, writing and speaking) in senior high schools.

This research also discusses on the relevance of the English textbook for senior high school used to the 2013 curriculum. It is the integration of four skills in learning English (reading, listening, speaking and writing) and as is recommended in 2013 English curriculum. In the state document of 2013 curriculum document. It is stated that the integration of required skills in learning a subject is of great important for the students.

Based on the background, the researcher aims to analyze the HOTS on the English Textbook class $X$ for Senior and Vocational High School published by Ministry of Education entitled "Bahasa Inggris" This book is designed based on the 2013 curriculum and used by English teachers and learners in the classroom activities. The researcher decides to conduct a research paper entitled An Analysis of Higher Order Thinking Skills (HOTS) on English Textbooks (Compulsory) for the tenth grade of Indonesian Senior High Schools. Therefore, this current study was guided by two research questions:

1. How is the composition of the higher order thinking skills in the four skills tasks in the textbook of Bahasa Inggris Kelas X SMA/SMK/MA?

2. Are the materials in the textbook "Bahasa Inggris Kelas X SMA/SMK/MA" for Senior High School Grade X relevant to the 2013 curriculum?

\section{METHODS}

This study adopted the descriptive qualitative of research. The descriptive method means "any research that describes a setting or events in terms" (Whitehurst et al., 2014). Hence, the researchers adopted this type of research as the study seeks to evaluate to what extent the HOTS are available in 'Bahasa Inggris SMA/SMK/MA Kelas X" textbook. 


\section{Instruments}

The content analysis card was used to collect, describe and analyze data regarding the availability of HOTS in language skills tasks of English for Senior High School and Vocational Senior High School Grade X in the light of the suggested checklist in the analysis of content. The items of the content analysis card were divided into three main domains (analysis, synthesis and evaluation). Besides, the content analysis card will show to advisors so that the researchers could benefit from their comments and suggestions for further modifications.

\section{Source of Data}

The English Textbook entitled "Bahasa Inggris SMA/SMK/MA Kelas X" is the title of English course book that was analyzed by the researcher. The authors of the textbook are Utami Widiati, Zuliati Rohmah and Furaidah. The textbook was published by Pusat Kurikulum dan Perbukuan Balitbang Kemendikbud in 2017. This course book was created for Senior High School (SMA, SMK, MA and MAK) grade X.

\section{Data Analysis Procedures}

The data of this research was the suitability of the materials in the English textbook with the criteria of a good English textbook. The course book utilizes the most update the 2013 curriculum of English subject. In analyzing the data the researcher used some phases of qualitative data proposed by Whitehurst (2014), which include:

1. Compiling: The researcher sorts the data from administered tasks of English textbook.

2. Disassembling: In this case, the researcher tries to classify the data into HOTS and LOTS level skills.

3. Reassembling: the researcher depicts the data and serves it into content analysis card.

4. Interpreting: the researcher describes the collected data and analyzed it by using interpretation and supported by theories and advisors.

5. Concluding: the research concludes the result of the research which is proven by the data and theories.

\section{Data Collection Technique}

In this research, two techniques were used to administer the data of the English textbook. They were data analysis, and documentation. The list of document evaluation was used to take data. The collected data was analyzed with the use of descriptive qualitative method. This research was categorized as content analysis. There were 15 chapters in collecting the data. 


\section{FINDINGS}

The composition of higher order thinking kills in Language skills tasks in English textbook "Buku Bahasa Inggris SMA/SMK/MA Kelas $X^{\prime}$.

Based on the data analysis, it was found that the composition of HOTS in language skills tasks in English Textbook Bahasa Inggris SMA/SMK/MA Grade $X$ is different. The dominant composition of HOTS was in writing skill, which was 51 out of 142 tasks, followed by speaking skill which was 45 tasks reading skill 20 tasks and listening skill as the lowest composition of HOTS (2 tasks). The description of the task of each language skills will be given in respective order, for example of High Order Thinking skills in reading tasks can be seen in the table below:

Table 1. Content Card Analysis of HOTS and LOTS in Reading skill

\begin{tabular}{|c|c|c|c|c|c|}
\hline No & Task & Skill & HOTS & LOTS & $\begin{array}{c}\text { Basic } \\
\text { Keyword }\end{array}$ \\
\hline 1 & $\begin{array}{l}\text { Task 2: } \\
\text { Create as many questions as you can based on the story. Use question words } \\
\text { such as who, when, where, why, how. Then, exchange your questions with a } \\
\text { classmate sitting next to you. Discuss them together. } \\
\text { Example: } \\
\text { 1. Once upon a time there was an old couple who didn't have a child. They lived in } \\
\text { a small house near the village forest. } \\
\text { Where did the old couple live? }\end{array}$ & Reading & $X$ & & Create \\
\hline
\end{tabular}

Based on the data above, reading skill provides 20 tasks of HOTS. It is obvious that students are driven to create as many questions. This task arrangement for the synthesis the questions from reading text with the use questions words such as what, where, why, how then the students should exchange questions with a classmate and discuss them together. This task applies HOTS development, in particular, creating also discussing the tasks in English.

In reference to the data above, there are 17 tasks discovered as LOTS such information about knowledge and comprehension, additionally reading text as indicated in questions for students in the English textbook "Buku Bahasa Inggris SMA/SMK/MA Grade X". Whereas tasks are made for students only to identify contents of reading text. Similarly, the data of listening skill as the lowest task provided in the textbook. In reference data below, listening skill only took 2 tasks of HOTS perform that students are driven to fill the gap in song's lyric and follow how should pronounce the lexical things by using a drilling technique. This is also categorized as HOTS development as students only manage with repeating their English in 
pronouncing words or sentences. Those same cases also happen the discussion.

Table 2. Content Card Analysis of HOTS and LOTS in Listening skill

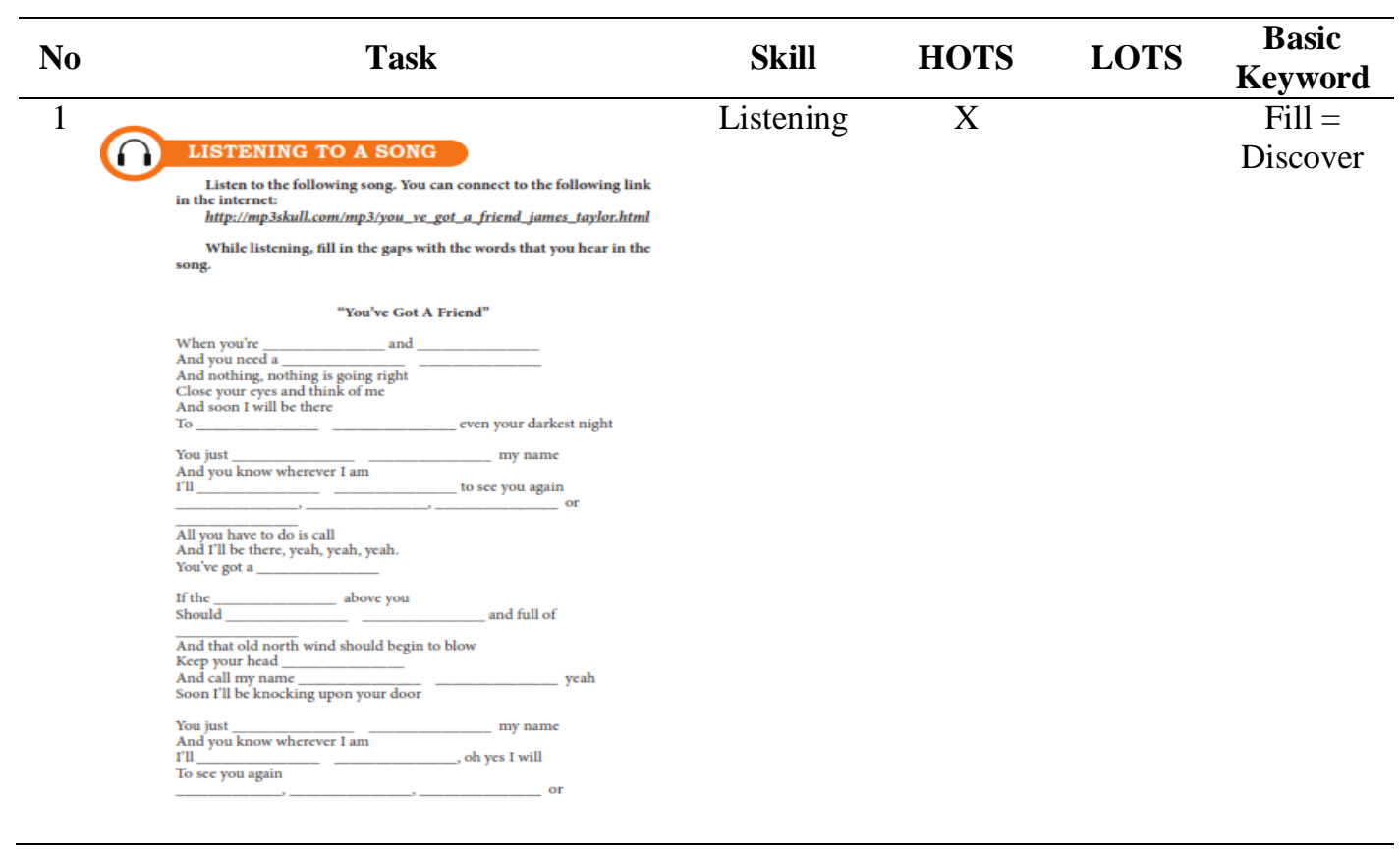

The questions of listening skills above are oriented to the LOTS as questions are dominated by discussing. For example, tasks only deal with factual questions that require understanding and memorizing the text. In other words, those questions do not instruct students to analyze and evaluate the questions. On the other hand, the information below performs that writing skills provided 51 Tasks of HOTS which students are determined best to apply HOTS with writing recount text about chronology of the battle of Surabaya. The students are engaged to create events in battle of Surabaya using their word or sentences.

Table 3. Content Card Analysis of HOTS and LOTS in Writing skill

\begin{tabular}{lllllc}
\hline No & Task & Skill & HOTS & LOTS & $\begin{array}{c}\text { Basic } \\
\text { Keyword }\end{array}$ \\
\hline
\end{tabular}


Analyzing Higher Order Thinking Skills on the...

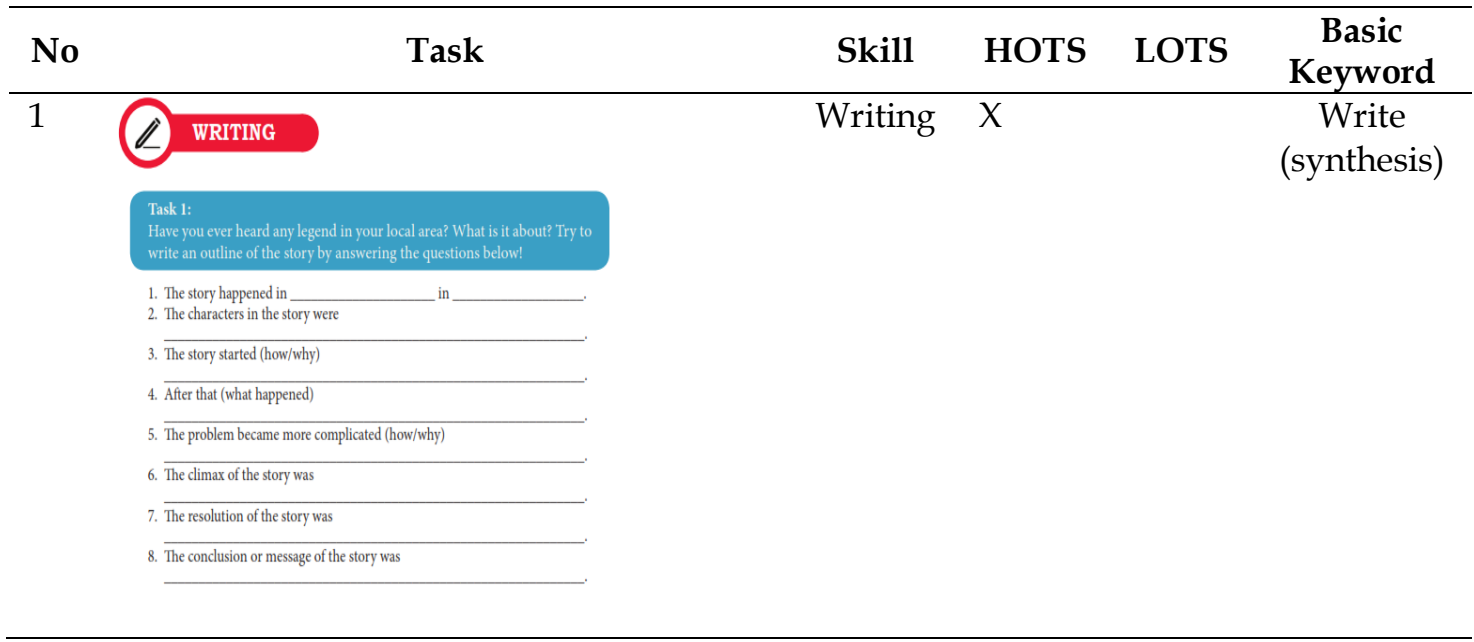

The data above shows that writing is a part of HOTS development as students for creating a text. The presentation of grammar/structure and vocabulary in the task could be done inductively. The students are then asked to deconstruct the text with the use of real or imaginary one which language forms such as grammar/structure, vocabulary, and pronunciation in their own words. In this case, students could apply higher-order thinking skills in synthesis the texts depending on the language focus which is rewrite. Toward the application of the HOTS, students could produce the rule of grammar or structure based on the text. This leads them to create the strategy of deconstructing the texts which drive them among the higherorder questions.

In this analysis, the researcher also found 19 tasks of LOTS in writing skills which some questions that require students only to discuss information about the main idea of the paragraph. These parts were tested in all LOTS of writing skill. The following area discusses the classification of main idea under the knowledge levels. The synthesis level of speaking skill is oriented to the development of HOTS as most of questions are dominated by factual questions with 45 tasks of HOTS.

Table 4. Content Card Analysis of HOTS and LOTS in speaking skill

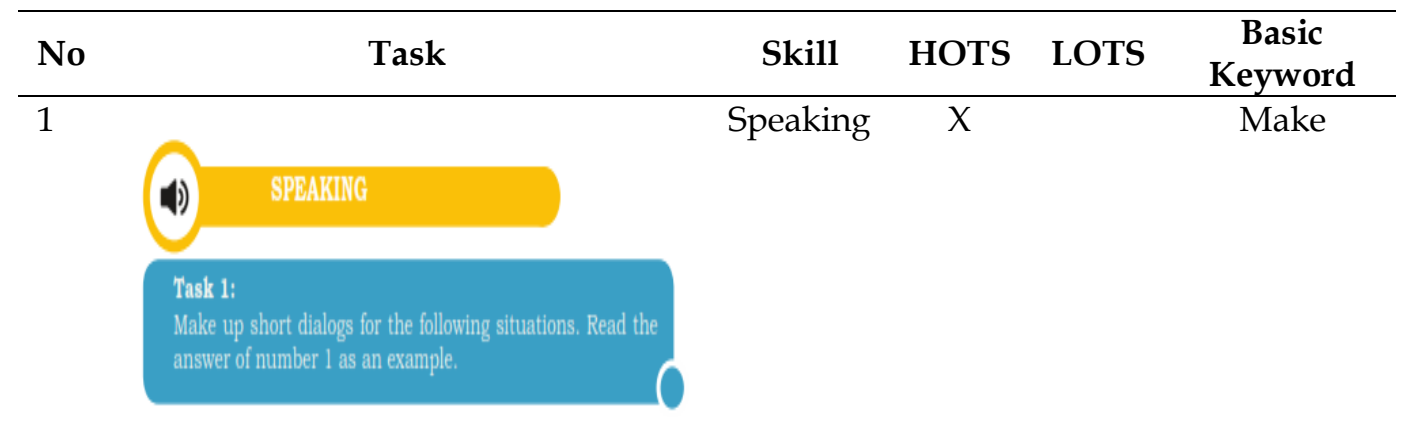


The tasks in table above describe factual questions which require creating a short dialog for following situations. In other words, those questions do not drive students to analyze and evaluate the text. Only one question, namely C5 (create) is categorized as a HOTS question, which make the dialog for being situation. The tasks in content card analysis are samples of speaking skills categorized under certain subskills of LOTS. There are 19 tasks in the content card analysis. The question seeks a repetition of vocabularies. For instance, it requires students to use their existing knowledge and understand English vocabulary based on certain contexts. The questions under this category (knowledge), only appeared nine times in the entire data involved in this study.

\section{Relevancy of Tasks in English Textbook "Buku Bahasa Inggris SMA/ SMK/ $M A^{\prime \prime}$ grade $\mathrm{X}$ to the 2013 Curriculum.}

Based on the data analysis of HOTS and LOTS composition in English textbook "Buku Bahasa Inggris SMA/SMK/MA/MAK Kelas X" it is found that the book is relevant to the 2013 Curriculum. This book is intended to help teacher in assessing the kind of complex thinking. The detail composition can be seen in the following table.

Table 5. Number of Tasks that are relevant to the 2013 Curriculum based on HOTS Level

\begin{tabular}{lc}
\hline \multicolumn{1}{c}{ Level of HOTS } & Categories \\
\hline Analysis & 87 tasks \\
\hline Synthesis & 59 tasks \\
\hline Evaluation & 2 tasks \\
\hline
\end{tabular}

The information above describes that from total of 252 tasks in the textbook, the analyzing skill obtain 87 tasks while the synthesizing skill obtains 68 tasks and evaluating skills obtains 2 items task

The majority tasks in the textbook are mostly relevant (chapters 2, 3,4, $5,6,7,8,9,10,13,14,15)$ of HOTS and of what they are stated in the syllabus of English curriculum 2013. Next, only 3 (two) chapters were irrelevant (Chapter 1,11,12) with HOTS. It is caused by most of tasks provide LOTS basic key words. This part is explaining the example of tasks in textbook analyses in which it is described in words to be more specifically explained. The relevancy of the English textbook "Buku Bahasa Inggris SMA/SMK/MA/MAK Kelas X" is accelerated to Brookhart theory (2010) in her book entitled "How to assess HOTS". He said that " a blue print for High School to assess of an accountable book for higher-order thinking. Based on The criteria of this theory, HOTS in a textbook should be consisted of: analyze, create and evaluate. 


\section{DISCUSSION}

The composition of HOTS in language skills tasks in English textbook of "Buku Bahasa Inggris SMA/SMK/MA Kelas X"

The findings of the research show the number of HOTS tasks in the English textbook entitled "Buku Bahasa Inggris SMA/SMK/MA Kelas X" is sufficient to fulfill the demand of the Ministry of Education Decree Number 22 of 2016. The four language skills (reading, listening, writing and speaking) are significant in the implementation of the 2013 Curriculum. Based on the Minister of Education (2013) states that the implementation of English skills in learning is very essential for the learners for their upcoming critical thinking.

In writing as productive skill, we can see as the highest skill appears of HOTS task (51 tasks). They were asked to write sentences and paragraph, filling in form, diary writing dialog writing and letter. In speaking as second highest skill of HOTS, there was several tasks instructed to students, such as discussion, reporting, role play, picture describing. Next, for the receptive skill reading provided 20 tasks of HOTS. Students were asked to do multiple choice, completion item, true/false and matching item. Last listening as the lowest skill (2 tasks) were demanded the students to listen the teacher repetition and listen the song. These claims are in line with $\mathrm{Wu} \&$ Pei (2018) who claim that in order to know well the relevancy of the HOTS of the English textbook itself with the 2013 Curriculum, then it is crucial to conduct research on analyzing the English textbook materials.

The finding above is different from by Margana (2015) that the English textbooks used for SVHS students in Indonesia are developed under the basic keywords of LOTS. The tasks of the English textbooks are concerned about knowing and memorizing the language competences for instance structure or grammar, pronunciation vocabulary. In addition, the tasks for the development of receptive macro-language skills such as listening and reading are only oriented to testing practices that articulate the factual questions instead of analytical questions.

Furthermore, this information determines the failure of the achievement of English. The teachers and students are unable in preparing any level of high order thinking skills. the above claims are in line with those of implementation of HOTS. The pupils are only driven to deal with systemic knowledge which is oriented to understanding the outer layer of the language system as stated by Kiong et al,. (2012).

The implementation of the productive language skills (writing and speaking) shows as performed in the English textbooks focuses on the application of the practice with the factual of memorize methods which mostly apply the use of drilling ways. This also happens in the implementation of writing which is implemented to the scoring approach 
putting stress of recognizing sentences. This proof shows that the lack of learning the target language (English) on the grounds that learners are only suggested to deal with a systemic application which is oriented to the practice of the language composition as conducted by Azian et al (2017)

The result of the analysis concerns the HOTS in English language skills were relevant significantly. The English textbook shows that the majority of all materials in four skills of each chapter contains of high level thinking (148 tasks) and these skills were integrated well.

\section{The Relevancy of Tasks in English Textbook "Buku Bahasa Inggris $S M A / S M K / M A$ grade $X^{\prime \prime}$ to the 2013 Curriculum}

The compulsory English textbook needs a consideration in preparing task for every textbook in order to have a comprehension and balance of the assessment system. It can give a contribution for schools to have a teaching and learning model that facilitates students' higher order -thinking skills in order to make them understand their own cognitive, affective and psychomotor ability in making analysis, create and evaluation judgments and with tasks in textbook being part of the model. This is a crucial point in increasing individuals' learning performance and cognitive development. The right structures and components of every task are also important in identifying the effectiveness of a teaching and learning process.

Furthermore, as one of the stakeholders in the educational system who have access to students directly and organize students learning activities, teachers have to understand, practice and utilize HOTS in order to deliver learning skills effectively. Azlian et al (2017) stated that teachers need to fill their comfort zone and change from conventional to a modern method of developing knowledge in order to promote and enhance critical thinking skills among students. It is in line the Decree of the Ministry of Education Number 11 of 2005 Article 8, that teachers can recommend students who are able to have textbook that focus on HOTS. Azlian et al (2017) stated that the lack of teaching and learning preparation might contribute to the failure of HOTS implementation in the classroom.

The findings also indicate that the important point for the English textbook to integrate HOTS in their teaching and learning activity in order to facilitate the critical thinking process in the classroom. The students will be able to comprehend and use language across variety of contexts and learning with their experience and this makes the learning more effective and efficient. Tarescavage \& Ben-Porath (2014) concluded that discussions of reading texts will be more effective when the textbook "involve the student in creating a shared and dynamic comprehension of the student's reading interests and processes" Critical thinking involve out of students to improve cognitive ability and enhance their performance on high level tasks. 
The Textbook is one of media to develop the strategies and skills necessary in 2013 Curriculum. High Level tasks are important parts of students' language learning assessment. It is vital for teachers to also understand the types of questions that should be given to facilitate students' capacity in learning English with various types of texts and materials. In this activity, teachers will be able to produce high reasoning abilities for students that will assist them learn with tasks that require HOTS.

The implementation of HOTS in Indonesian education system is relevant to current educational demands. In fact, the majority of High Schools' student faced difficulties in solving tasks of HOTS (Margana,. 2015). In this case the students' difficulties can be identified by analyzing students' errors in solving tasks. It is accelerated with Piaget's Theory cited in Philip (2014) "the learners from twelve years upwards only able to concentrate their thoughts on things and they can perform the variety of task involving use of hypothesis.

\section{CONCLUSION AND SUGGESTION}

From the findings above, it can be concluded that first, the content of higherorder thinking skills in tasks of the compulsory English textbook for the tenth grade used at Senior High Schools is relevant to the 2013 English curriculum. It has fulfilled the standard that is suggested by Decrees of the Ministry of Education.

Second, the composition of HOTS in language skills task shows that the majority of all materials in four skills were integrated well. Therefore, the result of the analysis of HOTS is positively relevant. Based on the finding and discussion, there are some suggestions in the following.

a. The teachers to train students extensively on the implementation of the HOTS to achieve the goals targeted in the 2013 Curriculum well.

b. The textbook should not only be compatible with the current curriculum, but also possess a characteristic of students.

c. The further researchers are advised to take more representative English textbooks, especially those published recently, as research materials for a more thoughtful conclusion.

\section{REFERENCES}

Abdul Aziz Ahmad, A., Ismail, F., Ibrahim, N. M., \& Samat, N. A. (2017). Investigating the Implementation of Higher Order Thinking Skills in Malaysian Classrooms: Insights from L2 Teaching Practices. Sains Humanika. https://doi.org/10.11113/sh.v9n4-2.1361

Brookhart, S. M. (2010). How to Assess Higher-Order Thinking Skills in Your Slassroomin Your Classroom. In Assess Thinking Higher-Order Skills. 
Kemendikbud. (2016). Permendikbud Nomor 22 Tahun 2016 Tentang Standar Proses Pendidikan Dan Menengah. Jakarta: Kemendikbud

Kiong, T. T., Yunos, J., Hassan, R., Heong, Y. M., Hj Hussein, A., Yunos Jailani, Hassan Razali, Heong, Y. M., \& Hussein Atan Hj. (2012). Thinking skills for secondary school students in Malaysia. Journal of Research, Policy \& Practice of Teachers $\mathcal{E}$ Teacher Education.

Margana, M. (2016). Voices of English Teachers and Students on Blended Culture as a Model of English Language Teaching and Learning at Vocational High Schools in Yogyakarta. Mediterranean Journal of Social Sciences. https://doi.org/10.5901/mjss.2016.v7n3p459

Mutrofin, L., Nur, M., \& Yuanita, L. (2017). DEVELOPING TEACHING MATERIALS USING 5E MODEL OF INSTRUCTION TO INCREASE STUDENTS' HIGHER ORDER THINKING SKILLS. JPPS (Jurnal Penelitian Pendidikan Sains).

Phillips, D. C. (2014). Encyclopedia of Educational Theory and Philosophy. In Encyclopedia of Educational Theory and Philosophy. https:/ / doi.org/10.4135/9781483346229

Rahmawati, F. (2013). Pengaruh Pendekatan Pendidikan Realistik Matematika dalam Meningkatkan Kemampuan Komunikasi Matematis Siswa Sekolah Dasar. Prosiding SEMIRATA 2013.

Tarescavage, A. M., \& Ben-Porath, Y. S. (2014). Psychotherapeutic outcomes measures: A critical review for practitioners. Journal of Clinical Psychology. https://doi.org/10.1002/jclp.22080

Tomlinson, M., Solomon, W., Singh, Y., Doherty, T., Chopra, M., Ijumba, P., Tsai, A. C., \& Jackson, D. (2009). The use of mobile phones as a data collection tool: A report from a household survey in South Africa. BMC Medical Informatics and Decision Making. https:/ / doi.org/10.1186/1472-6947-9-51

Whitehurst, G. J. R., Chingos, M. M., \& Lindquist, K. M. (2014). Evaluating Teachers with Classroom Observations Lessons Learned in Four Districts. Brown Center on Education Policy.

Wu, Y., \& Pei, Z. (2018). An Investigation of Critical Thinking Manifested in the Questions of EFL Textbooks for Tertiary-Level English Majors of China. American Journal of Education and Learning. https://doi.org/10.20448/804.3.2.72.84 